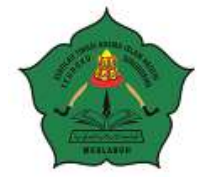

AT-TASYRI' Jurnal Ilmiah Prodi Muamalah

P-ISSN: 2085-2541, E-ISSN: 2715-7865

Volume 13, Nomor 2, Desember 2021

https://ejournal.staindirundeng.ac.id/index.php/Tasyri

\title{
PROSES PENGAJUAN TAGIHAN MELALUI APLIKASI ESPM PADA MASA COVID DI KPPN MEULABOH
}

\author{
Zaida Mutia \\ Fakultas Ekonomi, Universitas Teuku Umar \\ Rusma Setiyana* \\ Fakultas Ekonomi, Universitas Teuku Umar \\ *rusmasetiyana@utu.ac.id
}

\begin{abstract}
Abstrak
eSPM sebagai aplikasi yang berbasis web menjadi salah satu aplikasi yang dapat membantu proses pengiriman SPM pada masa pandemi Covid-19 di Kantor Pelayanan Perbendaharaan Meulaboh. Penelitian ini bertujuan untuk mendeskripsikan proses pengajuan tagihan melalui aplikasi eSPM pada masa pandemi Covid-19, penilaian satuan kerja dan kendala yang dihadapi baik dari pihak operator maupun satuan kerja terkait aplikasi eSPM, dan menganalisis penggunaan aplikasi eSPM. Populasi penelitian yang digunakan adalah satuan kerja yang berada di 4 kabupaten wilayah Aceh. Metode penelitian yang diimplementasikan adalah metode deskriptif kualitatif dengan memanfaatkan data primer berupa wawancara dan data sekunder berupa dokumen. Data dianalisis dengan menggunakan hitungan presentase. Hasil penelitian menunjukkan bahwa proses pengajuan tagihan melalui aplikasi eSPM dapat dilakukan dengan mengikuti langkah-langkah sederhana di dalam aplikasi eSPM. Berdasarkan dari segi manfaatnya, aplikasi eSPM dapat mempermudah pekerjaan satuan kerja, dapat memangkas waktu dan biaya perjalanan satuan kerja. Meskipun telah dikategorikan baik namun terdapat beberapa kendala yang dihadapi oleh responden baik dari petugas KPPN maupun satuan kerja dalam penggunaan aplikasi eSPM, yakni adanya ketidakstabilan jaringan, gangguan pada server aplikasi dan terjadinya penambahan tugas pada petugas KPPN. Terakhir, jumlah SPM yang diusulkan lebih sedikit, namun jumlah SPM yang ditolak lebih besar.

Kata Kunci: Pengajuan Tagihan, eSPM, Kantor Pelayanan Perbendaharaan Negara (KPPN)
\end{abstract}

\begin{abstract}
eSPM as a web-based application is one application that can assist the process of sending SPM during the Covid-19 pandemic at the department of Treasury Service in Meulaboh. This study aims to describe the process of submitting bills through eSPM during the Covid-19 pandemic, the assessment given by work units and the obstacles faced by both operator and work units related to eSPM, and to analyze the use of eSPM. The research population used was work units located in 4 districts of the Aceh region. The research method implemented was descriptive qualitative method by utilizing primary data in the form of interviews and secondary data in the form of documents. The data were analyzed by using a percentage count. The results of the study indicate that the process of submitting bills through eSPM can be carried out by following several stages provided in eSPM. In terms of benefits, eSPM is able to simplify the work of work units, save time and travel costs especially for work units. Although it has been categorized as good, there are several obstacles faced by respondents in using eSPM, namely network instability, disruption to the application server and the occurrence of additional tasks
\end{abstract}


for the department of Treasury Service officers. Finally, the total of SPM proposed through eSPM by the work units is less yet the total of those which has been rejected.

Keywords: Billing Submission, eSPM, Department of Treasury Service

\section{A. PENDAHULUAN}

Kantor Pelayanan Perbendaharaan Negara (KPPN) adalah instansi yang bergerak di bidang keuangan. Beberapa tugas utama KPPN sebagaimana yang tertuang dalam Peraturan Menteri Keuangan nomor PMK/234/KMK.01/2015 pada Tanggal 21 Desember tentang Organisasi dan Tata Kerja Kementrian Keuangan adalah "melaksanakan kewenangan Perbendaharaan dan Bendahara Umum Negara (BUN), penyaluran pembiayaan atas beban anggaran, serta penatausahaan penerimaan dan pengeluaran anggaran melalui dan dari kas Negara berdasarkan peraturan perundang-undangan”. Dalam menjalankan fungsinya, KPPN melakukan pengujian Surat Perintah Membayar (SPM) berdasarkan peraturan perundang-undangan dan penyaluran pembayaran atas beban APBN. Menurut undang-undang nomor 17 tahun 2003 pasal 3 ayat 4 menyebutkan bahwa "APBN mempunyai fungsi otoritasi, perencanaan, distribusi, pengawasan, stabilisasi, dan alokasi”. Untuk itu, perlu adanya pengelolaan APBN sebaik mungkin agar apapun yang menjadi tujuan dari pembangunan dapat dituntaskan dengan efektif dan efisien.

Namun saat ini Indonesia sedang mengalami musibah yaitu mewabahnya virus Covid 19. Pandemi covid 19 ini mengharuskan masyarakat untuk menjaga jarak agar tidak terpapar virus yang berbahaya ini. Hal ini menyebabkan berbagai pelayanan umum terhambat termasuk yang di alami oleh KPPN Meulaboh terutama dalam proses pengajuan tagihan melalui Surat Perintah Membayar (SPM). Untuk meminimalisir ketidakstabilan pelayanan dan mengingat peran KPPN yang sangat penting yakni memastikan belanja negara tetap tersalurkan Kementerian Keuangan berinisiatif mencari solusi agar dapat melaksanakan tugas dan pelayanan dengan sempurna. Salah satunya membuat sebuah aplikasi untuk melaksanakan Pengujian Surat Perintah Membayar secara daring. Adapun aplikasi yang dimaksud adalah eSPM (Elektronik Surat Perintah Membayar ).

Aplikasi eSPM ini tentu saja termasuk kedalam inovasi yang berbasis Teknologi Informasi dan Komunikasi (TIK) dimana pada setiap aplikasi terdapat kemudahankemudahan yang menjadi pertimbangan bagi setiap pengguna (Hasanudin \& Fitra, 2020). Dengan adanya aplikasi eSPM diharapkan mampu memangkas waktu dan biaya terutama dalam penggunaan kertas. Dalam rangka meningkatkan mutu Layanan ke Stakeholder Kantor Pelayanan Perbendaharaan Negara (KPPN) Meulaboh Aceh Barat diperlukan analisis pengajuan tagihan melalui aplikasi eSPM.

Penelitian mengenai analisa aplikasi telah banyak dilakukan salah satunya penelitian yang dilakukan oleh kurnia (2020) yang berjudul "Analisis Sistem Layanan Mobile Banking Dalam Menarik Minat Nasabah Di PT Bank Syariah Mandiri Kantor Cabang Pembantu Yogyakarta Kaliurang”. Hasil penelitian ini menunjukkan bahwa meskipun aplikasi ini terdapat beberapa kendala namun sistem layanan Mobile Banking BSM yogyakarta kaliurang telah menarik minat nasabah karena telah memberikan kemudahan serta dapat memenuhi kebutuhan nasabah. Penelitian selanjutnya berjudul "Analisis Dan Perencanaan Aplikasi Sistem Informasi 
Penelitian Dan Pengabdian Masyarakat LPPM STT Terpadu Nurul Fikri“" yang ditulis oleh Ratnasari \& Tawakal (2017). Hasil penelitian tersebut menyatakan bahwa aplikasi LPPM STT dapat membantu pihak LPPM dalam mengelola kegiatan penelitian dan pengabdian masyarakat. Penelitian selanjutnya dilakukan oleh Mukhtaromin (2018) yang berjudul "Kepuasan Pengguna Sistem Aplikasi Keuangan Tingkat Instansi (SAKTI) Pada Badan Pendidikan Dan Pelatihan Keuangan (BPPK)“. Hasil dari penelitian tersebut menunjukkan bahwa nilai kinerja faktor 4,05 sehingga dapat dikatakan bahwa aplikasi SAKTI yang digunakan sudah efektif dan responden puas dengan cara kerja menggunakan aplikasi SAKTI.

Berbeda dengan penelitian yang telah disebutkan diatas, aplikasi yang akan dianalisa pada penelitian ini adalah eSPM yang digunakan oleh satuan kerja yang berada di empat Kabupaten Aceh. menunjukkan kualitas informasi dan kualitas layanan yang dilakukan oleh KPPN Meulaboh melalui aplikasi eSPM berpengaruh positif terhadap kepuasan satuan kerja dan dapat membantu satuan kerja dalam menjalankan tugasnya.

Rumusan masalah dalam studi ini adalah:

1. Bagaimana proses pengajuan tagihan melalui aplikasi eSPM di KPPN Meulaboh?

2. Bagaimana penilaian satuan kerja terhadap aplikasi eSPM?

3. Apa saja kendala yang dihadapi oleh satuan kerja selama proses pengajuan tagihan melalui aplikasi eSPM?

4. Bagaimana analisis penggunaan aplikasi eSPM?

Adapun tujuan dari penelitian ini adalah untuk menggambarkan bagaimana proses pengajuan tagihan melalui aplikasi eSPM dan untuk mengetahui kendala yang dihadapi oleh satuan kerja(satker)selama proses pengajuan tagihan melalui aplikasi eSPM di KPPN Meulaboh.

Hasil dari penelitian ini diharapkan dapat bermanfaat bagi instansi sebagai bahan pertimbangan dan masukan khususnya bagi KPPN Meulaboh. Bagi pihak akademik,hasil penelitian ini diharapkan dapat menjadi sebuah referensi terkait eSPM. selain itu, penelitian ini juga dapat menambah pengetahuan dan wawasan mengenai aplikasi pengajuan tagihan eSPM bagi satuan kerja maupun bagi penulis sendiri.

\section{B. KAJIAN PUSTAKA KPPN Meulaboh}

Kantor pelayanan perbendaharaan negara (KPPN) merupakan sebuah isntansi yang bergerak khusus pada bagian keuangan. Berdasarkan Peraturan Menteri Keuangan Nomor 262 / PMK. 01 / 2016 tentang Organisasi dan Tata Kerja Instansi Vertikal Direktorat Jenderal Perbendaharaan, pasal 31 dikatakan bahwa "KPPN Tipe A mempunyai tugas melaksanakan kewenangan perbendahraan dan bendahara umum negara, penyaluran pembiayaan atas beban anggaran, serta penatausahaan penerimaan dan pengeluaran anggaran melalui dan dari kas negara berdasarkan peraturan perundangundangan".

Selanjutnya, berdasarkan Peraturan Menteri Keuangan RI nomor PMK 100/PMk.01/2012 tentang organisasi dan tata kerja instansi vertikal Direktorat Jenderal Perbendahraan meliputi:

- Kabupaten Aceh Barat= 34 satuan kerja (satker)

- Kabupaten Aceh Jaya = 21 satuan kerja (satker)

- Kabupaten Nagan Raya = 19 satuan kerja (satker)

- Kabupaten Simeulue $=21$ satuan kerja (satker) 
- Masyarakat/pemangku kepentingan lainnya yang memerlukan pelayanan.

Secara geografis kota Meulaboh terletak di bagian barat Provinsi Aceh dan merupakan Kabupaten Aceh Barat yang mempunyai jarak lebih jauh dengan Kabupaten Simeulue yang menempuh waktu selama \pm 18 jam lamanya. Untuk itu terhitung dari 1 Juli 2011 agar mempermudah akses layanan kepada satuan kerja yang berada di Simeulue telah dibuka layanan filial KPPN Meulaboh di Sinabang.

Namun, dikarenakan pandemi KPPN filial yang berada di Sinabang tidak dapat beroperasi seperti sediakala. Karena adanya anjuran untuk menjaga protokol kesehatan. Sesuai Keputusan Menteri Kesehatan Republik Indonesia nomor HK.01.07/MENKES/382/2020 tentang mematuhi protokol kesehatan guna untuk mencegah dan pengendalian CORONA VIRUS DISEASE (Covid 19) seperti yang dilakukan oleh Kantor Pelayanan Perbendaharaan Negara Meulaboh. Meskipun di tengah pandemi, namun pelayanan yang mereka lakukan tidak pernah berkurang. Mengingat peran KPPN yang sangat penting yakni memastikan belanja negara tetap tersalurkan karena pengelolaan keuangan yang baik akan berdampak positif bagi negara kita. Pada setiap instansi memiliki beberapa bentuk pelayanan yang berbeda-beda mulai dari pelayanan secara tatap muka yang dilakukan sebelum pandemi maupun pelayanan secara daring yakni ketika pandemi. Pelayanan secara daring terutama proses pengajuan tagihan SPM dilakukan dengan menggunakan aplikasi yang berbasis web yakni aplikasi eSPM.

\section{Pengajuan Tagihan SPM}

Pengajuan tagihan merupakan teknik pengusulan dana yang dilakukan oleh pihak yang berwenang atau satuan kerja yang ditunjuk melalui bendahara pengeluaran yang nantinya akan diuji kelengkapan dan kebenarannya. Berdasarkan Surat Keputusan Pemerdagi nomor 21 Tahun 2011 pasal 1 ayat 70, pengertian Surat Perintah Membayar (SPM) adalah "Dokumen yang diterbitkan oleh pengguna anggaran/kuasa pengguna anggaran untuk penerbitan SP2D atas beban pengeluaran DIPA SKPD" hal ini sama dengan pendapat yang dikemukankan oleh peneliti sebelumnya Syafira J.A (2020). Secara detail, Korobu (2016) menjelaskan SPM adalah suatu proses penting dimana pengelola penyisihan yang merupakan pengelola susulan dari mekanisme pengajuan SPP. Proses tersebut dimulai dengan pengujian SPM terlebih dahulu, pengujian tersebut berupa pengujian tentang kelengkapan-kelengkapan dokumen yang dikirim. Untuk itu SPM bisa dikeluarkan apabila pengeluaran yang diajukan tidak membatasi/melebihi pagu anggaran yang tersedia.

Adapun jenis-jenis SPM yang dapat diajukan petugas mencakup Gaji Induk, Gaji Susulan, Non Gaji, Gaji Lainnya, GUP, Penghasilan PPNPN Induk, Pemotongan Penyaluran Dana Desa, Penyaluran Dana Desa, Penghsilan PPNPN Susulan, Non Gaji Kontraktual, Up,Kekurangan Gaji, Retur, SPM THR Gaji, SPM-KP-Pajak, GTUP Nihil, TUP, dan SPM Gaji 13 (Kemenkeu, 2020).

\section{Aplikasi eSPM}

Ditjen Perbendaharaan, Hadiyanto (2020) menyampaikan bahwa aplikasi eSPM adalah aplikasi yang digunakan sebagai alat untuk proses pengiriman SPM secara daring oleh satuan kerja untuk proses pencairan dana. Dengan kata lain, aplikasi eSPM ini merupakan sistem penyampaian ADK dan dokumen melalui jaringan internet dimana satuan kerja tidak harus mendatangi kantor 
KPPN secara langsung. Lebih rinci, aplikasi eSPM adalah aplikasi yang berpedoman pada web yang dipakai untuk media pengajuan dokumen elektronik kontrak, dokumen elektronik RPD harian, dokumen elektronik gaji, dokumen elektronik SPM, ke Kantor Pelayanan Perbendaharaan Negara. Aplikasi e-SPM sendiri diatur dalam Surat Edaran Dirjen Perbendaharaan Nomor SE31/PB/2020 tentang Mekanisme Pengiriman Dokumen Tagihan Secara Elektronik pada masa pandemi Covid-19 (Corona Virus Disease 2019).

Penggunaan aplikasi eSPM dilakukan untuk menggantikan layanan pencairan anggaran melalui surat elektronik satuan kerja yang telah terdaftar di Kantor Pelayanan Perbendaharaan Negara di Meulaboh Aceh Barat. Aplikasi eSPM tersebut digunakan untuk keperluan Surat Perintah Membayar (SPM) yang berupa pengajuan, penerimaan, pemeriksaan dan penolakan SPM. Dengan adanya aplikasi eSPM tersebut maka pelayanan secara tatap muka yang ada di KPPN Meulaboh dapat diminimalisir. Hal ini dilakukan sebagai langkah awal dalam mencegah penyebaran virus Covid 19 yang semakin memburuk.

Aplikasi eSPM sangat membantu satuan kerja dalam menjalankan tugas mereka pada saat pandemi. Selain itu, aplikasi eSPM juga sudah aman digunakan karena sudah dialukan pengecekan terlebih dahulu. Sesuai dengan Peraturan Menteri Keuangan Nomor 177/PMK.05/2017 tentang adanya pelaksanaan piloting penerapan tanda tangan elektronik. Maka dengan penggunaan sertifikat elektronik sebagai pengganti tanda tangan basah dalam setiap pengiriman dokumen dapat disampaikan bahwa aplikasi eSPM ini sudah aman untuk digunakan oleh satuan kerja. Tujuan dari diciptakan aplikasi eSPM adalah untuk melancarkan administrasi pemerintah agar lebih efektif dan efesien.
Sehingga melancarkan pelaksaan tugas satuan kerja dan KPPN Meulaboh untuk melaksanakan tugas dan fungsi pelaksanaan APBN. Selain itu aplikasi eSPM juga diciptakan agar dapat menghemat kertas. Seperti yang kita ketahui bahwa setiap aplikasi yang diciptakan yaitu untuk meringankan pekerjaan.

\section{DATA DAN METODOLOGI}

Penelitian ini menggunakan metode deskriptif kualitati f untuk menggambarkan bagaimana proses pengajuan tagihan yang dilakukan melalui aplikasi eSPM dan kendala yang dihadapi oleh satuan kerja di empat kabupaten yakni Aceh Barat, Aceh Jaya, Nagan raya dan Simeulue. Jumlah populasi pada penelitian ini adalah sebanyak 98 satuan kerja. Namun, responden dari penelitian ini hanya melibatkan satu operator aplikasi eSPM dan semua satuan kerja yang datang langsung ke KPPN Meulaboh.

Terdapat dua sumber data dalam penelitian ini, yaitu data primer yang diperoleh dengan cara wawancara. Data primer yang dikumpulkan pada bulan Juli Agustus Tahun 2021 ini mencakup empat pertanyaan terkait aplikasi eSPM dan kendalanya. Selanjutnya data sekunder yang berupa dokumentasi yang berbentuk tulisan diperoleh dari website DJPB yang diunduh pada bulan Juli Tahun 2021. Adapun lokasi dilakukannya penelitian ini adalah di Kantor Pelayanan Perbendaharaan Negara (KPPN) Meulaboh Aceh Barat yang beralamat di Jalan Sisingamangaraja No. 03 Desa Drien Rampak Kecamatan Johan Pahlawan Kabupaten Aceh Barat.

Selanjutnya, data akan dihitung menggunakan rumus persentase yang dikutip dari Arikunto (2013). Rumus persentase tersebut adalah sebagai berikut:

$$
\mathrm{P}=\frac{\mathrm{F}}{\mathrm{N}} \mathrm{X} 100 \%
$$


Dimana,

$\mathrm{P}=$ Persentase

$\mathrm{F}=$ Jumlah jawaban responden

$\mathrm{N}=$ Jumlah seluruh responden

Adapun tafsiran dari masing-masing kriteria persentase adalah sebagai berikut:

Tabel 1

Kriteria Persentase

\begin{tabular}{cc}
\hline Kriteria (\%) & Tafsiran \\
\hline $76-100$ & Sangat baik \\
$55-75$ & Baik \\
$40-54$ & Cukup \\
$0-39$ & Buruk \\
\hline
\end{tabular}

D. HASIL DAN PEMBAHASAN

Proses Pengajuan, Penerimaan, Pemeriksaan, dan Penolakan Tagihan Melalui Aplikasi eSPM.

Berdasarkan hasil dari wawancara dengan operator aplikasi eSPM pada instansi KPPN Meulaboh, ada beberapa tahap proses pengajuan tagihan melalui aplikasi eSPM. Tahap pengajuan tagihan tersebut adalah sebagai berikut:

a. Proses pengajuan tagihan melalui aplikasi eSPM dilakukan oleh petugas satuan kerja yang telah memiliki user eSPM dengan cara mengunggah hasil pindaian dokumen. Dokumen tersebut berupa dokumen pendukung dimana pada dokumen ini data-data beserta kelengkapan-kelengkapan tertentu yang dikirim bersifat penting seperti SSP (Surat Setoran Pajak), daftar rekening penerima, daftar perubahan gaji, dan karwas kontrak.melalui sistem eSPM. eSPM dapat diakses pada situs sebagai berikut: www.espm.kemenkeu.go.id.

Sebelum satker membuka laman tersebut, satker harus sudah menyiapkan semua ADK SPM beserta syarat lainnya yang sudah ditanda tangan dan distempel oleh pihak yang berwenang dan kemudian dipindai. Untuk memulainya, satker/pengguna dapat mengklik laman di atas. Saat laman eSPM terbuka, pengguna wajib memasukkan 10 digit KIPS dan 6 digit kode satker yang diberikan oleh KPPN beserta password. Setelah login, pengguna dapat mencari menu "unggah" yang berada di sisi kiri layar komputer. Pilih menu SPM. Pada menu tersebut akan tertera tiga file yang harus diunggah, yakni ADK SPM, softcopy SPM dalam file zip, dan rekap SPM. Kemudian pengguna memilih menu "simpan". Setelah dokumen berhasil diunggah, pengguna dapat melihat proses SPM dimana pengguna nantinya dapat melihat apakah SPM diterima atau ditolak. Terakhir, klik menu "rekap SPM" (monitoring). Dokumen SPM tersebut nantinya akan diproses oleh petugas validasi pada seksi pencairan dana untuk diverifikasi kebenarannya. Apabila pada berkas tersebut masih terdapat kesalahan maka berkas akan dikembalikan disertai dengan alasan pengembalian. Maka dari itu satuan kerja perlu selalu memperhatikan dan melihat posisi atau status SPM yang telah mengirimkan dokumen. Jika berkas sudah benar maka selanjutnya diteruskan ke seksi bank untuk diterbitkan Surat perintah pencairan dana (SP2D). SP2D tersebut akan disalurkan dananya melalui bank operasional yang ditunjuk oleh KPPN Meulaboh.

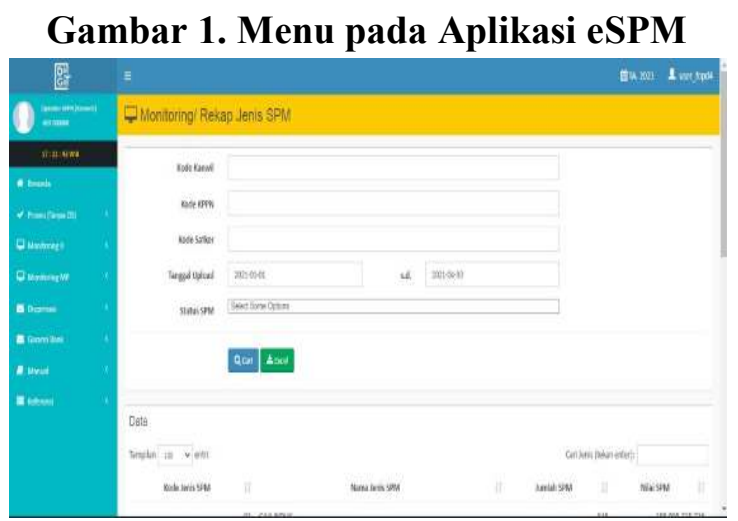

Sumber: Aplikasi eSPM 2021 
b. Proses penerimaan SPM secara teknis juga dilakukan secara online menggunakan aplikasi eSPM. Petugas validasi pada seksi pencairan dana akan mengunduh ADK SCAN dokumen serta mencetak satu rangkap dan mengupload ke sistem anggaran Negara yaitu SPAN.

c. Pemeriksaan SPM melalui apikasi eSPM dilakukan dengan dua sifat. Pertama, secara substantif, yaitu memeriksa apa saja dokumen yang dilampirkan dan bukti-bukti beserta dokumen pendukung lainnya. Selanjutnya, pemeriksaan dilakukan secara administratif, yaitu daftar belanja apa saja yang bisa dicairkan melalui SPM tersebut sehingga dapat meyakinkan bahwa dana yang diinginkan sesuai dengan apa yang tertulis pada SPM.

d. Penolakan SPM melalui aplikasi eSPM terjadi jika dalam pengajuan SPM tersebut ditemukan tidak memenuhi syarat pencairan secara subtantif, maka petugas validasi berhak untuk menolak dan mengembalikan dokumen tersebut melalui eSPM. pada saat proses pemeriksaan, status SPM yang dikirim masih dalam status proses namun jika ada penolakan SPM status tersebut berubah menjadi tolak manual hal ini dikarenakan terdapat kesalahan-kesalahan pada SPM. Untuk kasus tersebut, petugas validasi akan mencantumkan keterangan pada kolom SPM dengan menyebutkan alasan dan kekurangan dokumen sehingga dana yang diajukan tidak dapat dicairkan.

\section{Penilaian Satuan Kerja Terhadap Aplikasi Espm}

Adapun penilaian yang diberikan satuan kerja terhadap aplikasi eSPM sebagai berikut:

a. Alasan Menggunakan Aplikasi eSPM
Dalam penggunaan aplikasi eSPM tentunya satuan kerja memiliki alasan yang berbeda - beda baik dalam hal yang dapat memudahkan dalam menjalankan tugas maupun sebaliknya. Untuk lebih jelasnya dapat dilihat pada table dibawah ini.

Tabel 2

\section{Alasan Menggunakan Aplikasi eSPM}

\begin{tabular}{lc}
\hline \multicolumn{1}{c}{ Alasan } & Persentase \\
\hline Memudahkan satker & $75 \%$ \\
Menghemat biaya jalan & $25 \%$ \\
Total & $\mathbf{1 0 0 \%}$ \\
\hline
\end{tabular}

Sumber: Data diolah 2021

Berdasarkan tabel diatas, 75\% satuan kerja setuju bahwa aplikasi eSPM memudahkan satuan kerja dalam menjalankan tugasnya. dan $25 \%$ responden mengatakan bahwa aplikasi eSPM dapat menghemat dan memangkas biaya perjalanan satuan kejar menuju instansi KPPN Meulaboh. Dalam hal ini dapat disimpulkan dengan adanya aplikasi eSPM ini sangat membantu dan memudahkan satuan kerja dalam menjalankan tugas mereka. Dengan demikian, faktor kemudahan pada aplikasi eSPM ini dapat menarik perhatian dan minat para satuan kerja untuk menggunakan aplikasi tersebut terutama pada masa pandemi dimana para satuan kerja diharuskan untuk menjaga jarak dan mematuhi protokol kesehatan guna untuk mencegah diri dari terpaparnya virus covid 19. Adapun uraian yang telah disebutlkan oleh peneliti sebelumnya (Indrasari 2018) yang menyebutkan bahwa semakin besar produk/jasa yang ditawarkan maka kepuasan yang diterima pelanggan semakin tinggi, semakin tinggi tingkat kepuasan tersebut maka akan menimbulkan keuntungan bagi organisasi. 
Zaida Mutia \& Rusma Setiyana, Proses Pengajuan Tagihan...

b. Keamanan dan Kenyamanan Dalam Penggunaan Aplikasi eSPM

Tabel 3

\begin{tabular}{cc}
\multicolumn{2}{c}{ Keamanan dan Kenyamanan } \\
\hline $\begin{array}{c}\text { Keamanan dan } \\
\text { Kenyamanan Pemakaian } \\
\text { Aplikasi eSPM }\end{array}$ & Persentase \\
\hline Ya & $100 \%$ \\
Tidak & $0 \%$ \\
Total & $\mathbf{1 0 0 \%}$ \\
\hline
\end{tabular}

Tabel diatas menunjukkan bahwa para satuan kerja sudah merasa aman dan nyaman dalam penggunaan aplikasi eSPM ini dikarenakan pada setiap file/dokumen yang mereka kirim melalui aplikasi eSPM dapat terlindungi dan terjaga dengan ketat, sehingga para satuan kerja merasa yakin bahwa kerahasiaan sebuah dokumen yang mereka kirim dapat terjamin keamanannya. Hal ini sesuai dengan pendapat yang dikemukakan oleh Fietyata (2018) bahwa keamanan adalah sebuah bentuk kebebasan setiap individu. Artinya, seseorang akan merasa aman terhadap sesuatu yang sedang dikerjakan. Keamanan juga merupakan suatu bentuk menghindarkan diri dari hal-hal yang berbahaya.

c. Kepuasan Satuan Kerja Dalam

Menggunakan Aplikasi eSPM

Tingkat kepuasan satuan kerja dapat dilihat pada table di bawah ini :

Tabel 3

Kepuasan Satuan Kerja

\begin{tabular}{cc}
\hline $\begin{array}{c}\text { Tingkat Kepuasan Satker } \\
\text { terhadap Aplikasi eSPM }\end{array}$ & Presentase \\
\hline Ya & $77,8 \%$ \\
Tidak & $22,2 \%$ \\
Total & $\mathbf{1 0 0} \%$ \\
\hline Berdasarkan tabel diatas dapat \\
dijelaskan bahwa hampir $80 \%$ dari satuan \\
kerja mengatakan bahwa mereka merasa puas
\end{tabular}

dengan adanya aplikasi eSPM. Dengan kata lain, aplikasi eSPM sangat membantu satuan kerja dalam menjalankan tugas mereka terutama dalam memangkas biaya perjalanan dinas. Hal ini sama dengan pendapat peneliti sebelumnya yaitu Kurnia (2020). Sedangkan lebih dari $20 \%$ responden lainnya mengatakan sebaliknya terutama bagi para satuan kerja yang berada di pelosok daerah yang terkendala dengan jaringan sehingga menghambat tugas mereka saat menggunakan aplikasi eSPM. Meskipun demikian, para responden setuju bahwa aplikasi eSPM sudah layak untuk digunakan meskipun masih terdapat berbagai macam kendala.

\section{Kendala Yang Dihadapi Oleh Satuan Kerja Selama Proses Pengajuan Tagihan Melalui Aplikasi eSPM}

Berdasarkan data primer yang diperoleh dengan wawancara terhadap satuan kerja dan operator eSPM yang berada di KPPN Meulaboh ditemukan beberapa kendala dalam penggunaan aplikasi eSPM terutama dalam proses pengajuan tagihan. Kendala yang dihadapi oleh satuan kerja adalah adanya ketidakstabilan jaringan dikarenakan aplikasi ini berbasis web dan satuan kerja pun berada di berbagai daerah yang berbeda-beda.

Selain satuan kerja, karyawan KPPN Meulaboh yang bertugas pada seksi pencairan dana juga mengalami masalah yaitu dalam proses pelaksanaan pengajuan tagihan. Meskipun adanya aplikasi eSPM ini, petugas tetap harus melakukan percetakan kertas SPM. Berbeda dengan masa berlakunya pengajuan tagihan melalui eSPM, karyawan KPPN Meulaboh tidak perlu mencetak dokumen pada saat pengajuan tagihan dikarenakan satuan kerja dapat mengantarkan langsung SPM tersebut ke KPPN Meulaboh. Hal ini tidak sesuai dengan tujuan diciptakannya aplikasi eSPM yaitu untuk mengurangi percetakan kertas. Hal ini 
dilakukan karena saat ini pelayanan di KPPN Meulaboh berupa daring. Di samping itu, meskipun sudah dilakukan implementasi eSPM namun masih ditemukan beberapa hal yang masih menjadi pertimbangan, terutama pada satuan kerja. Pada aplikasi eSPM, satuan kerja harus selalu memperhatikan dan mengecek nomor suplier, nomor rekening dan data kontrak agar tidak terjadi perbedaan. Selain itu, dokumen-dokumen pendukung harus dikirim secara lengkap dan lain sebagainya. Selanjutnya kendala yang sering terjadi adalah kesalahan server pada aplikasi eSPM. kendala ini sama dengan pendapat yang dikemukaan oleh Ditjen Perbendaharaan (2020) yang menjelaskan bahwa kendala dari aplikasi eSPM yaitu pada kendala jaringan hal ini dikarenakan aplikasi eSPM ini berbasis web.

\section{Analisis Penggunaan Aplikasi eSPM}

Sesuai dengan Peraturan Menteri Keuangan no. 190/PMK.05/2012. SP2D atau Surat Perintah Pencairan Dana adalah dokumen yang dipakai untuk mencairkan anggaran melalui bank yang ditunjuk apabila SPM sudah diterima. SP2D dapat diterbitkan apabila pengeluaran yang diminta tidak melebihi Pagu anggaran yang tersedia dan didukung oleh kelengkapan dokumen yang sesuai dengan Peraturan Perundangundangan. Berdasarkan Peraturan Menteri Keuangan Nomor 82/pmk.05/2007 pasal 13 bahwa penerbitan SP2D paling lambat 2 (dua) hari kerja sejak diterimanya SPM secara lengkap dan benar oleh Direktorat Perbendaharaan/Direktorat Pengelola Kas Negara. Untuk melihat jumlah SP2D yang masuk dapat dilihat pada gambar berikut :
Gambar 2. Total Pengajuan SPM Sebelum Berlakunya eSPM

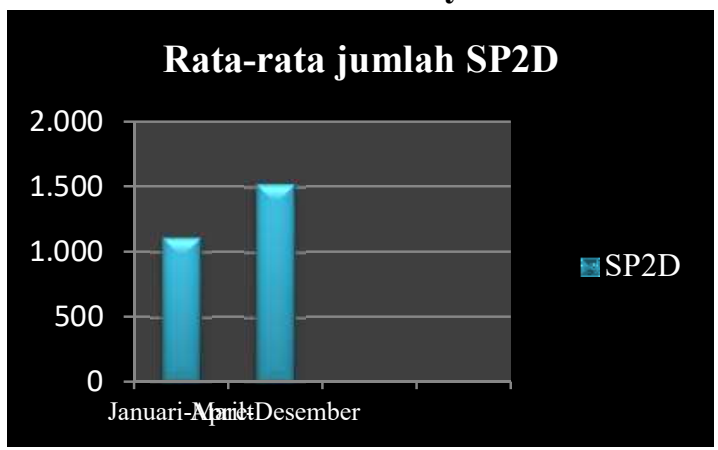

Sumber data: KPPN Meulaboh 2021

Dari diagram diatas dapat dijelaskan bahwa selama masa sebelum eSPM (Januari Maret) rata-rata pengajuan adalah 1,107 dan setelah eSPM (April - Desember) rata-rata jumlah pengajuan yang diajukan adalah 1,521 .

Dapat diambil kesimpulan sementara bahwa tingkat SP2D yang diterbitkan pada masa sebelum eSPM (Januari - Maret) lebih sedikit dibandingkan dengan masa sesudah eSPM (April - Desember). Hal ini dikarenakan dengan menggunakan aplikasi eSPM ini para satuan kerja dapat dengan mudah mengirimkan Surat Perintah Membayar (SPM) melalui email tanpa harus berkunjung langsung ke KPPN Meulaboh. Untuk itu dapat dikatakan bahwa aplikasi ini sangat membantu satuan kerja dalam menjalankan tugas tanpa adanya hambatan meskipun terkadang terdapat beberapa kendala jaringan.

\section{Gambar 3. Total Pengajuan SPM Setelah} eSPM

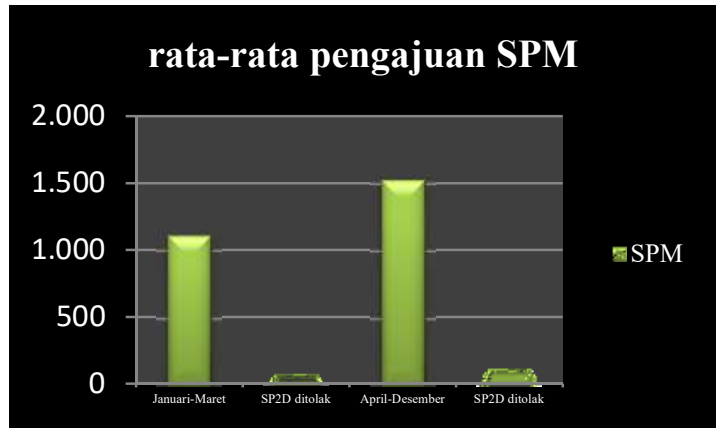

Sumber data: KPPN Meulaboh 2021 
Dari diagram diatas dapat dijelaskan bahwa total pengajuan yang diterima kppn adalah 1,107 (Januari-Maret) pada bulan tersebut terdapat SP2D yang ditolak sebesar 71. Pada bulan April-Desember rata-rata pengajuan SPM sebesar 1,521 dan SP2D yang ditolak adalah 112. SP2D yang ditolak tersebut akan dikembalikan datanya kepada satuan kerja yang bertugas. Dari SP2D yang ditolak dapat dikatakan bahwa penolakan tersebut akan menunda proses pencairan dana sehingga dana yang diminta belum bisa dicarikan.

Dari diagram diatas dapat diambil kesimpulan bahwa jumlah SPM yang masuk pada masa sebelum eSPM lebih sedikit dibandingkan dengan masa sesudah eSPM. namun SP2D yang ditolak pada masa sebelum eSPM lebih sedikit dibandingkan pada masa sesudah eSPM. hal ini dikarenakan dana yang diminta tidak sesuai dan melebihi pagu yang tersedia. Selain itu penolakan SP2D juga disebabkan oleh data atau nomor rekening yang tertulis tidak sesuai sehingga dana yang akan diterbitkan belum bisa dicairkan. dalam hal ini, tentunya para satuan kerja yang bertugas harus lebih teliti dan berhati-hati dalam mengirim SPM agar tidak terjadinya penolakan pada SP2D.

Dampak dari penggunaan aplikasi eSPM ini yaitu proses pengajuan tagihan/SPM menjadi lebih cepat dan mudah karena satuan kerja tidak perlu lagi berdatangan langsung ke KPPN Meulaboh. Hal ini tentunya sangat memudahkan mereka dalam menjalankan tugasnya. Namun meskipun begitu, pada aplikasi ini masih terdapat kendala yaitu kendala jaringan, gangguan server SPM dan data yang dikirim satuan kerja banyak kesalahan sehingga dapat menolaknya SP2D dan tertundanya pencairan dana.

\section{E. KESIMPULAN}

Berdasarkan dari hasil penelitian diatas maka penulis dapat menyimpulkan bahwa:

1. Proses penggunaan Aplikasi eSPM dalam pengajuan tagihan sudah memenuhi kebutuhan dan mempermudah satuan kerja. Selain itu penggunaan Aplikasi eSPM ini sangat membantu para satuan kerja dalam menjalankan tugas dan dapat menghemat biaya perjalanan. Dengan kata lain, penggunaan aplikasi eSPM sangat mempengaruhi hubungan antar karyawan yang berada di KPPN Meulaboh dengan satuan kerja yang berada di empat Kabupaten Aceh.

2. Penilaian satuan kerja pada aplikasi eSPM sudah sangat baik meskipun terdapat beberapa satuan kerja yang belum puas hal ini dikarenakan jarak yang jauh sehingga membuat ada gangguan pada saat pengiriman SPM.

3. Kendala yang dihadapi satuan kerja dalam aplikasi eSPM adalah adanya gangguan jaringan internet dan server, dan terjadinya penambahan tugas pada petugas eSPM karena harus mencetak SPM yang seharusnya dicetak oleh satuan kerja.

4. Penggunaan aplikasi eSPM mempermudah pekerjaan baik dari pihak KPPN maupun satuan kerja. Akan tetapi, hasil penelitian menunjukkan total pengajuan tagihan melalui eSPM lebih sedikit sedangkan total pengajuan tagihan yang ditolak lebih besar karena dana yang diajukan oleh pihak satuan kerja tidak sesuai atau melebihi pagu yang tersedia.

\section{BIBLIOGRAPHY}

Arifianto, C. F., \& Hasanudin, M. H. (2020). Pengaruh Kualitas Layanan yang Diterima Daring (PeSQ) Terhadap ESatisfaction Yang Dimediasi oleh 
Zaida Mutia \& Rusma Setiyana, Proses Pengajuan Tagihan...

Kepercayaan Daring atas Layanan Daring pada Implementasi e-SPM. Indonesian Treasury Review. 5(2020),. Indonesian Treasury Review: Jurnal Perbendaharaan, Keuangan Negara dan Kebijakan Publik, 5(4), 343-354. doi:10.33105/itrev.v5i4.238

Karianga, H. (2011). Partisipasi Masyarakat Dalam Pengelolaan Keuangan Daerah. Bandung: PT. Alumni.

Kemenkeu. (2010, Desember 10). Tata Cara Penerbitan Surat Perintah Membayar dan Surat Perintah Pencairan Dana. Dipetik Agustus 2021, dari Kementerian Keuangan Direktorat Jenderal Pajak: https://www.pajak.go.id/id/

Kemenkeu. (2016, Desember 30). Peraturan Menteri Keuangan Republik Indonesia Nomor 262/PMK.01/2016 Tentang Organisasi dan Tata Kerja Instansi Vertikal DJPb. Dipetik September 18, 2021, dari JDIH Kementerian Keuangan: https://jdih.kemenkeu.go.id.

Kemenkeu. (2020). Petunjuk Teknis Aplikasi eSPM. Dipetik Agustus 24, 2021, dari https://espm.kemenkeu.go.id

Kurnia, N. (2020). Analisis System Layanan Mobile Banking Dalam Menarik Minat Nasabah Di Pt Bank Syariah Mandiri Kantor Cabang Pembantu Yogyakarta Kaliurung. Skripsi. 75-77. Purwokerto: Institut Agama Islam Negeri Purwokerto.

Mukhtaromin. (2018). Kepuasan Pengguna Sistem Aplikasi Keuangan Tingkat Instansi (Sakti) Pada Badan Pendidikan dan Pelatihan Keuangan (BPPK).
Prosiding Simposium Nasional Keuangan Negara 2018. 1, hal. 588602. Badan Pendidikan dan Pelatihan Keuangan. Diambil kembali dari https://jurnal.bppk.kemenkeu.go.id/snk $\mathrm{n} /$

Ratnasari, D., \& Tawakal, H. A. (2017). Analisis dan Perencanaan Aplikasi Sistem Informasi Penelitian dan Pengabdian Masyarakat LPPM STT Terpadu Nurul Fikri. Jurnal Informatika Terpadu, 3(1). doi:10.54914/jit.v3i1.86

Sugiyono. (2006). Metode Penelitian Administrasi. Bandung: Alfabeta.

Syafira, A. J., Sabijono, H., \& Weku, P. (2020). Evaluasi Penerapan Dan Prosedur Penerbitan Surat Perintah Membayar Uang Persediaan Pada Badan Penanggulangan Bencana Daerah Kota Bitung. Going Concern: Jurnal Riset Akuntansi, 15(2), 204-210. doi:10.32400/gc.15.2.28191.2020

Yudha, F., \& Panji, A. M. (2018). Perancangan Aplikasi Pengujian Celah Keamanan Pada Aplikasi Berbasis Web. CyberSecurity dan Foresik Digital, 1(1), 1-6. doi:10.14421/csecurity.2018.1.1.1216

Zebua, A. M. (2020). Aplikasi Eletronik Manajemen Keuangan DIPA pada Lembaga Pendidikan Islam Negeri di Tengah Pandemi Covid-19 Sebagai Upaya WFH. Fikrotuna, 12(02). Fikrotuna: Jurnal Pendidikan dan Manajemen Islam, 12(2), 1681-1697. doi:10.32806/jf.v12i02.4086 